\title{
NOWE CZASY - NOWE MOŻLIWOŚCI. POLITYKA W NOWEJ PRZESTRZENI POLITYCZNEJ
}

„Wszystkie miejsca poza człowiekiem to już nie są te miejsca. Jedyne miejsce człowieka jest tylko w nim. Niezależnie, czy jesteśmy tu, gdzie indziej czy gdziekolwiek. Teraz czy kiedykolwiek. Wszystko, co na zewnątrz, to jedynie złudzenia, okoliczności, przypadki, pomyłki. Człowiek jest sam dla siebie tym ostatnim miejscem"2.

Wiesław Myśliwski

\section{Wstęp}

W kontekście przytoczonych słów Wiesława Myśliwskiego można by uznać za niezasadne zajmowanie się polityką, która z natury swej jest wykraczaniem poza jednostkę w kierunku osiągania dobra wspólnego. Jednak odnalezienie samego siebie zawsze otwiera na innych, na drugą osobę, na wspólnotę. Dlatego przekraczanie siebie dla dobra wspólnoty staje się przestrzenią działania człowieka osadzonego w określonym czasie. Dla współczesności ta przestrzeń poszerzyła się o wymiar wirtualny, dlatego celem tego artykułu jest refleksja nad możliwościami, jakie stwarza polityce pojawienie się owej przestrzeni cybernetycznej, wyzwaniami, jakie stawia człowiekowi współczesna przestrzeń polityczna, a także ukazanie człowieka działającego tu i teraz, w określonych uwarunkowaniach współczesnego świata i w sposób nieunikniony zanurzonego w świat polityki przez bierne i czynne prawo wyborcze. Stawiane będą też pytania o moralną ocenę indyferentyzmu politycznego, a także o to, czy netarchia i e-demokracja może stać się nową przestrzenią polityczną dla współczesnego człowieka. W przygotowaniu arty-

1 Mgr lic. Ewa Wnuk, doktorantka na Wydziale Teologicznym Uniwersytetu Szczecińskiego, Katedra Teologii Moralnej i Duchowości; e-mail: ewusia_w@interia.pl.

2 Wiesław Myśliwski, Traktat o łuskaniu fasoli (Warszawa, Społeczny Instytut Wydawniczy Znak, 2007). 
kułu posłużono się metodą krytycznej analizy wybranych tekstów, badań, dostępnych opracowań i obserwacji dotyczących prezentowanego tematu.

Dynamiczny rozwój najnowszych technologii nie może pozostać niezauważony w takiej dziedzinie jak polityka. Jednocześnie rozwój ten zmienia usytuowanie człowieka w świecie i sposoby wyrażania przez niego własnych wyborów. Internet wykorzystywany jest nie tylko w prowadzeniu kampanii wyborczych, promocji programów politycznych, ale również w rozwoju nowych ruchów społecznych ${ }^{3}$. Postęp technologiczny, związane z nim procesy przemian społecznych stawiają przed człowiekiem nowe wyzwania: może on zagubić się, zatracić w cybernetycznej przestrzeni, może też odnaleźć własną drogę i udoskonalać umiejętności, które otrzymał od Boga. Dotyczy to wrażliwej, a zarazem istotnej części ludzkiej działalności, jaką jest polityka.

\section{Jak zdefiniować przestrzeń?}

Przestrzeń definiuje się jako zbiór elementów, z uwzględnieniem ich struktury i wzajemnych odniesień, jako nieograniczony trójwymiarowy obszar, w którym zachodzą zjawiska fizyczne, ale także jako rozległy obszar bez granic czy też miejsce zajmowane przez przedmiot, odległość między elementami ${ }^{4}$. Zakres rozpatrywanych w niej zjawisk implikuje wyróżnienie przestrzeni w: matematyce, fizyce, geografii, astronomii, filozofii, antropologii i politologii. Dla nauk przyrodniczych przestrzeń wyraża się w postrzeganiu konkretnym i zmysłowym. Dla filozofii czy politologii będzie miała znaczenie abstrakcyjne, umysłowe, metaforyczne.

W matematyce przestrzeń jest jednym z podstawowych pojęć pierwotnych geometrii absolutnej i euklidesowej, stanowi nadrzędny zbiór, który zawiera inne zbiory poddawane analizie matematycznej ${ }^{5}$. W fizyce przestrzeń oznacza to, co nas otacza i w czym przebiegają wszystkie zjawiska fizyczne. Przestrzeń geograficzna oznacza powierzchnię ziemi w jej fizycznym, przyrodniczym, złożonym zróżnicowaniu. W antropologii rozumienie terminu przestrzeń zależy od kultury, w stosunku do której go odnosimy ${ }^{6}$.

Sposoby rozumienia przestrzeni w naukach społecznych można ujmować w kilku aspektach:

a) jako puste ramy, w których zachodzą określone zjawiska, niebędące jednak w żaden sposób przez tę przestrzeń warunkowane,

b) jako naturalna cecha obiektów (np. rozmiary),

c) jako odległość między obiektami,

d) jako systematyczny układ obiektów niosący określone znaczenia,

3 Maria Marczewska-Rytko, „Elektroniczny wymiar demokracji. Wybrane kwestie”, w: Demokracja elektroniczna. Kontrowersje i dylematy, red. M. Marczewska-Rytko (Lublin: Wydawnictwo UMCS, 2013), 43.

4 Słownik języka polskiego PWN, dostęp 27.12.2017, https://sjp.pwn.pl/sjp/przestrzen;2511263.html.

5 Witold Kołodziej, Analiza matematyczna (Warszawa: PWN, 2009), 14.

6 Więcej na ten temat w: Edward Twitchell Hall, Ukryty wymiar (Warszawa: Muza, 2003). 
e) jako zbiór granic i przeszkód w postrzeganiu i działaniu?

W polityce o przestrzeni można mówić w kategoriach konkretnych: terytorium państwa, określony okręg wyborczy. Można też rozumieć ją w sposób abstrakcyjny - jako relacje zachodzące pomiędzy podmiotami życia politycznego. W tych kategoriach można również mówić o wirtualnej przestrzeni, która stanowi swoiste miejsce - nie-miejsce. Tak więc dla prowadzenia rozważań natury polityczno-społecznej przestrzeń można rozumieć jako „wymiar, w którym obserwować możemy określone zjawiska”8 . „Współczesną przestrzeń polityczną możemy rozumieć jako konstrukcję myślową, wyznaczaną przez szereg komponentów: potrzebę polityzacji, socjalizację polityczną, uczestnictwo

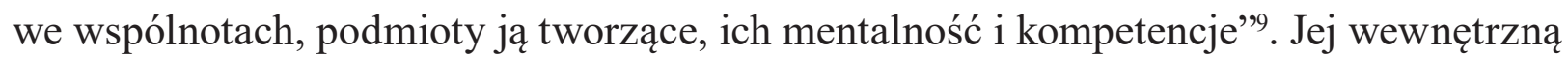
cechą są zmiany - zarówno powolne, jak i gwałtowne - wynikające z nieustannego rozwoju rzeczywistości społeczno-politycznej. Przestrzeń, w której rozgrywają się różne wydarzenia, definiowana przez zachodzące w niej procesy, staje się swoistą sceną. W takim rozumieniu można mówić również o scenie politycznej.

Dla zrozumienia powiązań polityki ze światem wirtualnym i ich wzajemnego oddziaływania należy wspomnieć również o przestrzeni cybernetycznej. Wszelkie procesy globalizacyjne - w tym procesy polityczne - nie byłyby możliwe bez internetu, bez systemów prognozowania, sterowania, a „sam internet bywa postrzegany jako najważniejsza innowacja od czasów Gutenberga"10. Cyberprzestrzeń definiuje się jako przestrzeń globalną, której nie ograniczają granice geograficzne, czas, uwarunkowania polityczne. Konstytutywną cechą cyberprzestrzeni jest sieciowość, a wirtualność - cechą potencjalną, zaś określając walory komunikacyjne, należy wymienić interaktywność, multimedialność i hipertekstowość ${ }^{11}$. W Rządowym Programie Ochrony Cyberprzestrzeni czytamy, że „cyberprzestrzeń to cyfrowa przestrzeń przetwarzania i wymiany informacji tworzona przez system sieci teleinformatycznych wraz z powiązaniami między nimi oraz relacjami z użytkownikami" "12. Dlatego współcześnie nie da się dobrze i skutecznie uprawiać polityki bez zaangażowania się w cyberprzestrzeń, m.in. w prowadzeniu działalności politycznej, wzajemnych interakcjach pomiędzy rządzonymi a rządzącymi, wzajemnej wymianie informacji i jej przetwarzaniu dla potrzeb polityki.

Posługując się w niniejszym artykule pojęciem „nowa przestrzeń polityczna”, wskazuje się na zmiany i rozwój rzeczywistości politycznej i społecznej oraz wzajemne współoddziaływanie polityki w cyberprzestrzeni na procesy polityczne. Posługiwanie się tym pojęciem ma na celu pokazanie, że przestrzeń działania polityki to nie tylko obszar danego kraju, okręg wyborczy, to nie tylko relacje zachodzące pomiędzy rzą-

7 Tomasz Zarycki, „Współczesna przestrzeń społeczno-polityczna Polski”, Studia Regionalne i Lokalne 23, 56 (1997): 13.

8 Zarycki, „Współczesna przestrzeń społeczno-polityczna Polski”, 7.

9 Współczesna przestrzeń polityczna. Ewolucja czy rewolucja?, 7.

10 Piotr Sienkiewicz, „Ontologia cyberprzestrzeni”, Zeszyty Naukowe WWSI 13, 9 (2015): 90.

11 Sienkiewicz, „Ontologia cyberprzestrzeni”, 92.

12 Sienkiewicz, „Ontologia cyberprzestrzeni”, 94. 
dzonymi i rządzącymi w realnej przestrzeni, ale także wszelkie polityczne działania „w” i ,poprzez” zaangażowanie nowych technologii.

Człowiek zawsze znajduje się w jakiejś przestrzeni, gdyż jest to wyraz jego bytowej egzystencji. Porusza się w niej, sytuując nie tylko siebie, ale i innych, tworząc określone grupy i społeczności. Przemieszcza się w określonej przestrzeni, a stosunek do niej jest określony miarą zawładnięcia jej, posiadania, zarządzania czy pokonywania. Można przyjąć, że przestrzeń to ogólna rama, w której centrum znajduje się poruszająca się istota ludzka ${ }^{13}$. Jest nie tylko potrzebą psychiczną, społeczną, ale także duchową. To w niej ludzie tworzą codzienną rzeczywistość, porządkują rzeczy i sprawy, a także koncepcje stworzone w umyśle ludzkim. Jednostka organizuje tę przestrzeń tak materialnie, jak i symbolicznie, w ramach sacrum i profanum, a także w ramach przestrzennych działań i relacji między członkami określonej grupy społecznej.

Czasy hiperkomunikacji zmieniają perspektywę postrzegania nowych form organizacji procesów społecznych i politycznych, zaś powstanie społeczeństwa informacyjnego zakłada wiele przemian technologicznych, które zostają zaangażowane w system sprawowania władzy, udziału obywateli w rządzeniu i osiąganiu dobra wspólnego.

\section{Przestrzeń polityczna w czasach współczesnych}

Nadejście globalizacji sprawiło, że minął czas izolacji różnych grup społecznych. Przestrzeń lokalna poszerzyła się, nie ogranicza człowieka, nie określa ostatecznie jego możliwości czy pozycji społecznej. Wcześniej społeczności lokalne „,były podstawowym elementem struktury społecznej, gmina stała się ich instytucjonalnym i politycznym wyrazem. Społeczności lokalne, zorganizowane w gminę, władały określonym terytorium, stanowiąc względnie zamknięty system - układ lokalny. Gdzieś ponad nimi, w innej przestrzeni, rozgrywała się przyspieszona historia wydarzeniowa, toczyły się wojny, upadały i powstawały monarchie, kształtowały się polityczne makrostruktury"14.

Globalizacja skróciła dystans, zmieniła rozumienie i postrzeganie przestrzeni lokalnej: to, co niegdyś odległe, stało się możliwe do osiągnięcia, przekraczalne. Mieści się w tym spojrzenie na przestrzeń polityczną. Według klasycznej definicji polityka to takie zarządzanie określoną grupą, społecznością, by osiągnęła określone dobro wspólne, jest to troska o wspólny dobrostan jednostek i całego społeczeństwa. Należy pytać: jak w dzisiejszej, poszerzonej przestrzeni lokalnej, życia w złożoności sieci, w nieograniczonych przepływach, w kompresji czasu i przestrzeni, w medialnej bliskości i swoistemu ujednoliceniu odnaleźć swój stosunek do troski o dobro wspólne. Należy przyjąć perspektywę - ja jako jednostka, która może czynnie wpływać na wybór polityków, na ocenę ich

13 Małgorzata Dziura, „Człowiek w przestrzeni (Ir)racjonalnej”, 1-2, dostęp 12.09.2017, http://www.filozoficznie. pl/3/32_M_Dziura_Czlowiek_w_przestrzeni_(ir)realnej.pdf.

14 Kazimierz Zbigniew Sowa, „Zmierzch i odrodzenie się lokalizmu w XX stuleciu”, w: Społeczeństwo i przestrzeń zurbanizowana, red. M. Malikowski, S. Solecki (Rzeszów, 2011), 286. 
pracy, zaangażowanie w projekty społeczno-polityczne oraz ja - jako ten, który może zostać wybrany przez społeczność, który bezpośrednio sprawuje władzę i - z mandatu demokratycznego realnie wpływa na jej kształt ${ }^{15}$.

Możemy dzisiaj mówić o przejściu od rozumienia przestrzeni w sposób euklidesowy czyli od wyraźnego zaznaczenia granic, określenia i oddzielenia centrum i peryferii do postrzegania globalnego, czyli przestrzeni globalnej, wielowymiarowej, z nieciągłymi subprzestrzeniami, które wzajemnie się przenikają. I tak lokalne decyzje polityczne, militarne, ekonomiczne podejmowane w jednym miejscu świata fluktuują na reakcje i relacje zachodzące w innych regionach globu. Decyzja o wyborze określonej grupy wpływu, partii politycznej czy przywódcy państwa rzutuje na nastroje na rynkach finansowych, na ocenę pozycji państwa na arenie międzynarodowej, na reakcje społeczne czy militarne w różnych rejonach świata. Oddziaływanie lokalne przenika do życia globalnego i odwrotnie - oddziaływanie globalne przenika do życia lokalnego.

Człowiek jako istota społeczna zanurzona w życie polityczno-społeczne ma nieustanny kontakt z informacjami, które przybliżają go i włączają w kosmopolityczne napięcia i problemy. Znikanie granic, unifikacja, przepływ wiadomości, bliski kontakt z przedstawicielami rożnych kultur z jednej strony powodują zachwianie uznanych systemów wartości i niepewności, z drugiej - wymuszają konieczność dostosowania się do zmieniających warunków, do elastyczności. Jedni w tej sytuacji angażują się intensywniej, inni przejawiają niechęć do uczestnictwa w życiu publicznym i mówią o świadomej absencji wyborczej. L. Porębski wyróżnił trzy aspekty wpływu internetu na przestrzeń polityki. Nazwał je ,więcej, szybciej, łatwiej”. Wskazał na aspekt ilościowy, na prędkość komunikacji i obniżenie kosztów funkcjonowania władzy. Oznacza to, że do obywateli może docierać większa liczba informacji, mogą oni łatwiej docierać do polityków, mają większą możliwość wymiany poglądów, a także możliwość kontaktu w dowolnym momencie, nawet wówczas, gdy urzędy nie są otwarte ${ }^{16}$.

Poszerzenie przestrzeni o nowe możliwości technologiczno-cybernetyczne daje poczucie sprawstwa i umożliwia przekraczanie nieprzekraczalnych dotąd granic. Zatomizowane społeczeństwo ponowoczesne z jednej strony sprzyja alienacji, wyłączeniu jednostek, zatopieniu we własnej czasoprzestrzeni. Z drugiej - otwiera na współudział, współuczestnictwo w sprawach, które dotąd były ograniczone bądź zarezerwowane dla wąskiej grupy. Polityka, zdaniem niektórych ${ }^{17}$, powinna być zarezerwowana dla elity świadomej, odpowiedzialnej, wykształconej. Formułując te poglądy, powołują się na demokrację ateńską, w której czynne i bierne prawo wyborcze było powszechne, ale owa

15 Wojciech Burszta, Antropologia kultury. Tematy, teorie, interpretacje (Poznań: Wyd. Zysk i S-ka, 1998$), 84$.

16 Leszek Porębski, „Więcej, szybciej, łatwiej. O radościach i smutkach związanych z elektroniczną demokracją”, w: Demokracja elektroniczna. Kontrowersje i dylematy, red. Maria Marczewska-Rytko (Lublin: Wydawnictwo UMCS, 2013), 13-31.

17 Maria Szyszkowska, „Koncepcje demokracji w dobie globalizmu”, dostęp 12.09.2017, http://szyszkowska.bloog.pl/id,5881317,title,KONCEPCJE-DEMOKRACJI-W-DOBIE-GLOBALIZMU,index.html?smoybbttica$\mathrm{id}=619 \mathrm{~b} 2 \mathrm{e}$. 
„powszechność” była zarezerwowana do wyraźnie zarysowanej grupy (dorośli, wolni mężczyźni, którzy posiadali status obywatela). Nowa, wirtualna przestrzeń sprzeciwia się takiemu ujęciu i skłania ku otwarciu i włączeniu szerszego kręgu obywateli w sprawy polityczne, nawet tych, a może zwłaszcza tych, którzy do tej pory nie chcieli w niej uczestniczyć. Zmienia więc elitarność demokracji w egalitarność.

Przestrzeń wirtualna staje się miejscem specyficznych interakcji z innymi użytkownikami - w tym interakcji na poziomie politycznym i społecznym. Zmienia się logika rządzenia i panowania. Ponieważ pojawia się przestrzeń ,bezgraniczna”, niedookreślona fizycznymi granicami, zmienia się znaczenie podstawowego atrybutu nowożytnych państw, czyli panowanie nad terytorium.

\section{Nowa przestrzeń - nowe możliwości?}

Określenie nowej przestrzeni politycznej wiąże się z przestrzenią wirtualną, czyli miejscem - nie-miejscem. Istnieją różne interpretacje i wyjaśnienia przestrzeni wirtualnej, dokonane przez niektórych teoretyków. Definiują oni przestrzeń wirtualną w kontekście kulturowo-politycznym jako „ostatnie stadium rozwoju przestrzeni społecznej”18:

- w ujęciu potocznym - określają ją jako sztuczność, iluzję, coś wyobrażonego lub niemożliwego,

- ujęcie odwołujące się do filozofii - definiuje wirtualność jako coś możliwego, ale nieaktualnie zaistniałego,

- ujęcie z perspektywy informatyki i przetwarzania danych - coś zapisanego w formie cyfrowej jako baza danych, oprogramowanie,

- jako utożsamienie z rzeczywistością generowaną przez komputery ${ }^{19}$.

Dla lepszego zrozumienia nowej - wirtualnej przestrzeni politycznej należy też wskazać, w jaki sposób podzielono politykę internetową, a mianowicie:

- polityka w sieci - wewnętrzna polityka społeczności internetowych, charakter wewnętrznych relacji, grup dyskusyjnych,

- polityka dotycząca sieci - „zwykła” polityka wpływająca na sieć - własność, dostęp, kontrola, cenzura,

- polityczne zastosowanie sieci - polityczne wykorzystanie sieci dla dokonywania zmian społecznych, kulturowych w świecie rzeczywistym ${ }^{20}$.

Cyberprzestrzeń staje się więc nową sferą, polem, „miejscem”, środowiskiem - rozproszonym, ale kreatywnym i stymulującym do aktywności na poziomie ogólnospołecznym. Zmiany kulturowo-społeczne, przemiany samoświadomości jednostek, nowe ruchy i prądy otworzyły również polityczną przestrzeń wewnętrznej odpowiedzialności jednostki za społeczność tak lokalną, jak i szerzej rozumianą. Przestrzeń wirtualna staje

18 Dziura, „Człowiek w przestrzeni (Ir)racjonalnej”, 5.

19 Dziura, „Człowiek w przestrzeni (Ir)racjonalnej”, 5.

20 Agnieszka Rothert, Cybernetyczny porządek polityczny (Warszawa: Aspra, 2005), 104. 
się nowym, sieciowym środowiskiem społecznym wspólnotą wirtualną. Internet jawi się więc jako wyznacznik nowego modelu organizacji społeczeństwa, a tym samym organizacji politycznej. Jednak ta wirtualna przynależność bywa oceniana krytycznie, bowiem (zdaniem właśnie owych krytyków) jest bardziej wspólnotą opartą na wyobrażeniach, nie zaś rzeczywistych relacjach osobowych, na korzeniach, na historii. Daje to możliwość łatwiejszego samowykluczenia - wyłączenia się z takiej wspólnoty. Jednostka współuczestniczy, współdziała o ile i na tyle, na ile sprzyja to jej indywidualnym korzyściom. Ma to znaczenie dla wspólnoty politycznej, która mimo pozornej zmienności (np. opieraniu się na kapryśnej presji społecznej, wahaniu sondażowym) wymaga stabilności, gdyż stanowi o realnym zabezpieczeniu dóbr jednostki i społeczeństw ${ }^{21}$.

Niektórzy autorzy uważają, że dotychczasowy sposób organizowania i przeprowadzania wyborów napotyka wiele barier i ograniczeń, takich jak wysokie koszty uczestnictwa, konieczność stosowania uproszczonej formuły pytań, które nie dają możliwości zastosowania pełnego zakresu odpowiedzi (referendum), utrudnienia dla osób z ograniczeniami ruchowymi, osób niepełnosprawnych, przebywających poza miejscem zamieszkania ${ }^{22}$. W tej sytuacji komunikacja elektroniczna postrzegana jest jako element konieczny dla sprostania wymogom demokracji.

Jak widać, współczesność staje się wyzwaniem dla przestrzeni politycznej, gdyż w cywilizacji postępu i presji rozwoju technologicznego, innowacyjności nieuniknione jest włączenie nowych technologii w świat polityki i ich silny wpływ na nią.

\section{Netarchia i e-demokracja jako nowy wymiar polityki}

W erze postępu technologicznego zaistniały propozycje stworzenia w zmienionej przestrzeni politycznej tzw. e-demokracji jako możliwości wyrażenia własnego zdania, oddania głosu w każdym momencie i z każdego miejsca na świecie. Tworzenie oddolnych form demokracji dałoby możliwość szerszej partycypacji wyborczej obywateli w przestrzeni publicznej i politycznej. Złożoność procesów globalizacyjnych i postępu technicznego spowodowała zmianę koncepcji przestrzeni politycznej, a Aleksander Sikora mówi o odejściu od centralizmu i autorytaryzmu, reguł, hierarchii społecznych i zastąpieniu ich przestrzenią sieciową. Uznaje ją za swego rodzaju grę między wieloma uczestnikami życia społeczno-politycznego - rządem, sektorem prywatnym, społeczeństwem obywatelskim. Mowa tu o tzw. netarchii. Jako proces (sposób rządzenia) preferuje podejmowanie decyzji, które będą dobre dla jak największej ilości grup lokalnych. Przestrzeń rządzenia poszerza się dzięki nowym formom komunikowania się. Możliwa staje się deli-

21 Mirosław Lakomy, Demokracja 2.0. Interakcja polityczna w nowych mediach (Kraków: Akademia Ignatianum, Wydawnictwo WAM, 2013), 128.

22 Mirosław Kutyłowski, „E-voting: głosowanie elektroniczne”, Infos. Zagadnienia Społeczno-Gospodarcze 10 (2009): 1-4, dostęp 30.11.2017, http://orka.sejm.gov.pl/wydbas.nsf/0/701c7f09abfe5c84c12575bd002de087/\$file/ infos_57.pdf. 
beracja, dyskusja i aktywne uczestnictwo, przede wszystkim tych, którzy wyrażą chęć i których dana decyzja dotyczy. Netarchia zmienia filozofię podejmowania decyzji w rządzeniu w sieci. Powstaje szeroka baza, sieć, przestrzeń, w której do procesu decyzyjnego wykorzystuje się szersze spektrum wiedzy o realnych problemach. Dzięki tak poszerzonej przestrzeni społecznej, politycznej, decyzyjnej jej uczestnicy widzą problemy z różnych punktów widzenia i w kontekście złożonych zależności.

Dzięki przestrzeni sieciowej polityka może stać się transparentna - zrównoważona: przez dostęp do sieci internetowej możliwa jest kontrola różnych klas i szczebli rządzenia. Poszerzenie przestrzeni politycznej o wymiar sieciowy może wpłynąć na poprawienie jakości relacji pomiędzy podmiotami życia społeczno-politycznego, a tym samym przełożyć się na realny, a nie tylko formalny wpływ na decyzje polityczne.

Netarchia to zaakcentowanie realizacji dobra wspólnego, rozumianego jako przyjęcie rozwiązań dobrych dla wszystkich stron, bądź umożliwienie realizacji postulatów mniejszościowych w obrębie grup, które tego pragną (polisocjetyzm). Poszerzenie rzeczywistości politycznej w rozumieniu netarchii dotyczy uznania, że sieć wirtualna staje się podstawą współczesnej tkanki i dynamiki społecznej. Wprowadza demokrację sieciową jako nowy mechanizm samorządzenia ludzi - sieci społeczne gwarantują dynamikę społeczną i kontrolę procesu politycznego ${ }^{23}$.

Nowa przestrzeń polityczna wzbudza oczywiście kontrowersje, gdyż stawia pytania czy powinna ograniczyć się do elektronicznej biurokracji, czy też ma objąć zarządzanie informacją polityczną? Czy można połączyć procedury demokracji bezpośredniej i pośredniej - udział w referendum, wypowiadanie się na forum publicznym, udział $\mathrm{w}$ wyborach z wykorzystaniem internetu, tzw. e-voting ${ }^{24}$ ? Ta odmieniona i poszerzona przestrzeń polityczna może dać osobie poczucie sprawstwa, wzmocnić pozycje jednostki w relacji obywatel - władza, a także realnie zmniejszyć koszty funkcjonowania administracji.

Dwaj autorzy, James Bohman i William Rehg, uważają, że demokracja oparta na dialogu z obywatelami ,odwołuje się do idei, zgodnie z którą usankcjonowane prawodawstwo wynika z publicznej deliberacji obywateli. Jako normatywne uzasadnienie legitymizacji, demokracja deliberatywna przywołuje ideały racjonalnego prawodawstwa, partycypacyjnej polityki oraz samorządności obywatelskiej. (...) Prezentuje ona ideał politycznej autonomii opartej na rozumowaniu obywateli"25.

Netarchia staje się więc filozofią polityczną, która wspiera sieci tak realne, jak i wirtualne. Gdzie jednak ma odnaleźć swoje miejsce człowiek - uczestnik tej nowej prze-

23 Marta du Vall, Marta Majorek, Agnieszka Walecka-Rynduch, red. Współczesna przestrzeń polityczna, Ewolucja czy rewolucja? (Kraków: Krakowska Akademia im. A.F. Modrzewskiego, 2011), 44.

24 Szerzej na temat e-votingu: Ryszard Balicki, „E-voting przyszłość demokracji?”, E-Biuletyn: elektroniczny biuletyn naukowy CBKE 3 (2008): 1-7, dostęp 29.11.2017, http://www.bibliotekacyfrowa.pl/Content/34346/E-voting. pdf.

25 James Bohman, William Rehg, „Deliberative Democracy. Essays on Reason and Politics” (Cambridge, 1997), IX, za: Bartosz Abramowicz, „Kryzys liberalnej demokracji - wyzwanie instytucjonalizacji polityki deliberacyjnej”, Przegląd Historyczno-Politologiczny 2 (2009): 73. 
strzeni? Pomimo jej obszerności w jej strukturze socjo-społecznej, według niektórych badaczy (Alexander Bard, Jan Soderqvist), wytworzą się obywatele klasy A, tzw. digitariat, oraz obywatele klasy B - „,konsumariat” czy tzw. ,teleproletariusze”. Jednostka może więc stać się czynnym uczestnikiem e-rzeczywistości politycznej bądź biernym konsumentem zawartości przestrzeni polityczneje ${ }^{26}$.

Pojawia się więc problem, na ile współczesna przestrzeń polityczna prowadzi do ekskluzji, a na ile do inkluzji społecznej. I w tej perspektywie wirtualny obszar polityki może mieć charakter horyzontalny, w którym niezależne jednostki o takiej samej pozycji, sile i władzy mają wspólny cel, a struktury tej organizacji charakteryzują się elastycznością w podejmowaniu obowiązków, współpracą, ,znikomą liczbą reguł wewnątrz organizacji; zdecentralizowanymi uprawnieniami decyzyjnymi oraz płaską strukturą"27. Tę przestrzeń Piotr Płoszajski nazywa heterarchią ${ }^{28}$. Autor mówi też o hiperarchii i definiuje ją jako dzielenie się wiedzą i informacją w sposób zbiorowy i masowy. Mówi, że jest to ,sieć multipołączeń między ludźmi, organizacjami i przedmiotami zmieniającymi wszystkie hierarchie"29. Oznacza to, że każdy element tej struktury może „dotrzeć” do tego samego „miejsca”, posiadając dostęp do tej samej wiedzy. Nazywa to symetrią informacyjną ${ }^{30}$.

Dla świata polityki oznacza to, że współczesny człowiek, jeśli tylko chce, może stać się częścią struktur, posiadając nieograniczony dostęp do informacji i wiedzy, z jednoczesną możliwością wpływania na decyzje i wybory (e-demokracja, e-voting). Pojawiła się również koncepcja mówiąca o tym, że otwartość, współpartnerstwo, dzielenie się zasobami i współdziałanie w perspektywie globalnej prowadzi do takiej samoorganizacji struktur społecznych, które potrafią zafunkcjonować bez hierarchii i zdefiniowanego przywództwa. Struktury te mogą mieć charakter płynny, nietrwały, a jednak skuteczny w realizacji poszczególnych celów wspólnotowych ${ }^{31}$. Koncepcja ta zakłada zaistnienie demokracji bezpośredniej na wszystkich etapach życia społecznego.

\section{Człowiek wobec nowej przestrzeni politycznej?}

Nowa przestrzeń polityczna zakłada poszerzenie przestrzeni publicznej. Nie jest już potrzebne osobiste, bezpośrednie spotkanie podmiotów interakcji. Sfera publiczna obejmuje wszelkie formy aktywności jednostki - także, a może przede wszystkim - w sieci. Daje to możliwość zaangażowania również tych grup społecznych, które do tej pory

\footnotetext{
26 Lakomy, Demokracja 2.0. Interakcja polityczna w nowych mediach, 131.

27 Lakomy, Demokracja 2.0. Interakcja polityczna w nowych mediach, 131.

28 Lakomy, Demokracja 2.0. Interakcja polityczna w nowych mediach, 132.

29 Lakomy, Demokracja 2.0. Interakcja polityczna w nowych mediach, 132.

30 Lakomy, Demokracja 2.0. Interakcja polityczna w nowych mediach, 132.

31 Lakomy, Demokracja 2.0. Interakcja polityczna w nowych mediach, 133.
} 
czuły się wykluczone lub nie chciały - z różnych względów - interesować się mikro czy też makropolityką ${ }^{32}$.

Dzięki tej nowej przestrzeni społeczeństwo otwiera się na dialog, zaangażowanie i aktywność. „Nowe technologie stanowić mogą rodzaj elektronicznej agory, przestrzeni dla decyzji politycznych, w których aktywnością wykazać się może nieograniczona liczba uczestników"33. Cyberprzestrzeń to zdecydowanie większy potencjał dla możliwości i przebiegu procesów politycznych. Informacja łatwiej i taniej dociera do odbiorcy, choć z drugiej strony - trudniej kontrolować treść, prawdziwość, jakość przekazywanych informacji na linii rządzący - wyborcy.

Duże znaczenie ma to, w jaki sposób człowiek - uczestnik tej przestrzeni - może i chce zaistnieć we współczesnej przestrzeni politycznej. Jego udział może mieć charakter nieformalny - z niewielkim stopniem partycypacji w procesach rządzenia i formalny z wyraźnie określoną rolą w państwowych i politycznych mechanizmach decyzyjnych. Istotny jest charakter deliberatywny, dyskusyjny, gdy to obywatele mogą brać udział w debacie publicznej ${ }^{34}$, a sieć umożliwia szybki i bezpośredni dostęp instytucji państwowych do wyników tej dyskusji.

L. Porębski nadaje człowiekowi - osobie, jednostce określone role, które może pełnić w przestrzeni demokracji elektronicznej. Mówi on o obywatelu, obserwatorze i kliencie. Obywatel przyjmuje postawę zaangażowania i szeroko zarysowanej aktywności w wirtualnym świecie (debaty, petycje, e-voting, udział w przedsięwzięciach, badaniach opinii publicznej). Obserwator używa sieci do pozyskania informacji na temat aktualnych procesów politycznych. Rola klienta (konsumenta) dotyczy korzystania z usług politycznych udzielanych przez państwo ${ }^{35}$. Jak widać, nowa przestrzeń polityczna to określone spektrum działania i zaangażowania. Istotne jest to ostatnie - zaangażowanie. Możliwa jest postawa indyferentyzmu politycznego, obojętności i bierności wobec materii rządzenia państwem czy spraw związanych ze społecznością lokalną. W każdej społeczności znajdzie się grupa obywateli niezaangażowanych - bądź w wyniku świadomego wyboru, bądź nieświadomej postawy. Każda z nich podlega pewnej ocenie moralnej i jest ciekawym tematem rozważań natury etycznej.

Poszerzony obszar polityczny włącza nowe grupy społeczne oraz jednostki w procesy demokratyczne. Przewiduje się odejście lub zmniejszenie znaczenia demokracji przedstawicielskiej na rzecz demokracji 2.0. Powstanie społeczeństwa „sieci obywateli” jest potencjalnie możliwe przede wszystkim ze względu na dorastające pokolenie Web 2.0, które - jak łatwo zaobserwować - nie wyobraża sobie życia, funkcjonowania bez

32 Lakomy, Demokracja 2.0. Interakcja polityczna w nowych mediach, 134.

33 Wojciech Gustowski, E-społeczność. Jak budować $i$ wykorzystywać społeczności internetowe w nowoczesnych działaniach marketingowych (Gliwice: Internetowe Wydawnictwo Złote Myśli, 2007), 7.

34 Leszek Porębski, Elektroniczne oblicze polityki. Demokracja, państwo, instytucje polityczne w okresie ewolucji informacyjnej (Kraków: AGH, 2001), 29-50.

35 Leszek Porębski, „Obywatel-konsument-obserwator. Główne wymiary wykorzystania Internetu w polityce”, Nowe Media 1 (2010): 161-162. 
łączności przez internet. Nowy obywatel w nowej przestrzeni politycznej - „obywatel 2.0" w przeciwieństwie do dotychczasowego rozmienia demokracji, przechodzi z modelu biernego do modelu partycypacyjnego ${ }^{36}$. „Demokracja 2.0 jest fenomenem obejmującym wzrost znaczenia nowych mediów jako platformy interakcji politycznej tak z perspektywy elit politycznych, jak i jednostek i ich grup dialogu w ramach społeczeństwa"37.

\section{Zakończenie}

Nowe technologie mogą odegrać wielką rolę jako katalizator nowatorskich koncepcji politycznych. Współczesny człowiek będzie musiał odnaleźć się w nowej przestrzeni politycznej nie tylko poprzez jej poznawanie, ale również sytuując się w niej ze swoją wrażliwością, z wyborami moralnymi, z działaniem zanurzonym w jego „tu i teraz”. Zarówno zaangażowanie, jak i obojętność na sprawy polityczne będzie decyzją, która wpłynie na rzeczywistość świata, w którym egzystuje. Z pewnością nowe technologie staną się w sposób nieunikniony istotnym elementem politycznej rzeczywistości współczesnego świata. Wciąż jednak to człowiek będzie decydował o sposobie i jakości ich wykorzystania.

Podsumowując - zmieniająca się rzeczywistość i nieustanne poszerzanie się świata o nowe przestrzenie zmuszają niejako świat polityki do szukania nowych rozwiązań, ale także mobilizują obywateli do innego zaangażowania w poszukiwaniu kreatywnego i skutecznego działania na rzecz dobra wspólnego.

\section{Bibliografia}

Balicki, Ryszard. „E-voting przyszłość demokracji?”. E-Biuletyn: elektroniczny biuletyn naukowy CBKE 3 (2008): 1-7. Dostęp 29.11.2017. http://www.bibliotekacyfrowa.pl/Content/34346/E-voting.pdf.

Bohman, James, William Rehg. „Deliberative Democracy. Essays on Reason and Politics”. Cambridge, 1997. Za: Bartosz Abramowicz, „Kryzys liberalnej demokracji - wyzwanie instytucjonalizacji polityki deliberacyjnej". Przegląd Historyczno-Politologiczny 2 (2009): 70-77.

Du Vall Marta, Marta Majorek, Agnieszka Walecka-Rynduch, red. Współczesna przestrzeń polityczna, Ewolucja czy rewolucja?. Kraków: Krakowska Akademia im. A.F. Modrzewskiego, 2011.

Dziura, Małgorzata. „Człowiek w przestrzeni (Ir)racjonalnej”: 1-9. Dostęp 12.09.2017. http:// www.filozoficznie.pl/3/32_M_Dziura_Czlowiek_w_przestrzeni_(ir)realnej.pdf.

36 Lakomy, Demokracja 2.0. Interakcja polityczna w nowych mediach, 151.

37 Lakomy, Demokracja 2.0. Interakcja polityczna w nowych mediach, 152. 
Gustowski, Wojciech. E-społeczność. Jak budować i wykorzystywać społeczności internetowe w nowoczesnych działaniach marketingowych. Gliwice: Internetowe Wydawnictwo Złote Myśli, 2007.

Hall, Edward Twitchell. Ukryty wymiar. Warszawa: Muza, 2003.

Kołodziej, Witold. Analiza matematyczna. Warszawa: PWN, 2009.

Kutyłowski, Mirosław. „E-voting: głosowanie elektroniczne”. Infos. Zagadnienia Społeczno-Gospodarcze 10 (2009): 1-4. Dostęp 30.11.2017. http://orka.sejm.gov.pl/wydbas. nsf/0/701c7f09abfe5c84c12575bd002de087/\$file/infos_57.pdf.

Marczewska-Rytko, Maria. „Elektroniczny wymiar demokracji. Wybrane kwestie”. W: Demokracja elektroniczna. Kontrowersje i dylematy, red. M. Marczewska-Rytko, 41-46. Lublin: Wydawnictwo UMCS, 2013.

Myśliwski, Wiesław. Traktat o łuskaniu fasoli. Warszawa: Społeczny Instytut Wydawniczy Znak, 2007.

Porębski, Leszek. Elektroniczne oblicze polityki. Demokracja, państwo, instytucje polityczne w okresie ewolucji informacyjnej. Kraków: AGH, 2001.

Porębski, Leszek. „Obywatel-konsument-obserwator. Główne wymiary wykorzystania Internetu w polityce”. Nowe Media 1 (2010): 159-179.

Porębski, Leszek. „Więcej, szybciej, łatwiej. O radościach i smutkach związanych z elektroniczną demokracją". W: Demokracja elektroniczna. Kontrowersje i dylematy, red. Maria Marczewska-Rytko, 13-31. Lublin: Wydawnictwo UMCS, 2013.

Roskal, Zenon, Eugeniusz. „Koncepcje przestrzeni w nauce i filozofii przyrody”. Roczniki Filozoficzne 54, 1 (2008): 279-294.

Rothert, Agnieszka. Cybernetyczny porzadek polityczny. Warszawa: Aspra, 2005.

Sienkiewicz, Piotr. „Ontologia cyberprzestrzeni”. Zeszyty Naukowe WWSI 13, 9 (2015): 89-102.

Słownikjęzyka polskiego PWN. Dostęp 27.12.2017. https://sjp.pwn.pl/sjp/przestrzen;2511263. html.

Szyszkowska, Maria. „Koncepcje demokracji w dobie globalizmu. Dostęp 12.09.2017. http://szyszkowska.bloog.pl/id,5881317,title,KONCEPCJE-DEMOKRACJI-W-DOBIEGLOBALIZMU,index.html?smoybbtticaid=619b2e.

Zarycki, Tomasz. „Współczesna przestrzeń społeczno-polityczna Polski”. Studia Regionalne i Lokalne 23, 56 (1997): 13.

\section{Streszczenie}

Celem artykułu jest przedstawienie wyzwań, jakie stawia człowiekowi współczesna przestrzeń polityczna. Autor wyjaśnia szeroki i wąski zakres przestrzeni politycznej, a także różnicuje ją od przestrzeni publicznej. Ukazuje człowieka działającego tu i teraz, w określonych uwarunkowaniach współczesnego świata i w sposób nieunikniony zanurzonego w świat polityki przez bierne i czynne prawo wyborcze. Stawia pytania o moralną ocenę indyferentyzmu politycznego, a także o to, czy netarchia i e-demokracja może stać się nową przestrzenią polityczną dla współczesnego człowieka. W przygotowaniu artykułu posłużono się metodą kry- 
tycznej analizy wybranych tekstów, badań, dostępnych opracowań i obserwacji dotyczących prezentowanego tematu.

Słowa kluczowe: człowiek, przestrzeń, polityka, globalizacja, netarchia, e-demokracja

\begin{abstract}
NEW TIMES - NEW OPPORTUNITIES. POLITICS IN THE NEW PUBLIC SPACE

The aim of the article is to present the challenges that the contemporary political space poses to a human. The author explains the broad and narrow scope of political space and also differentiates it from the public space. A human being is presented as acting here and now, in definite conditions of the modern world and immersed inevitably in the world of politics because of passive and active electoral law. The author asks questions about the moral evaluation of political indifference and also whether the netarchy and e-democracy can become a new political space for the modern man. When preparing this article, a method of critical analysis of selected texts, researches, available studies and observations on the selected topic was used.
\end{abstract}

Keywords: human being, space, politics, globalization, netarchy, e-democracy 